\title{
Kosmopolitanisme, Negosiasi, dan Resistensi: Identitas Perempuan Muslim dalam Iklan Kosmetik Muslim di Indonesia
}

\author{
Ferry Fauzi Hermawan \\ Institut Teknologi Bandung \\ ferryfauzihermawan@itb.ac.id
}

\begin{abstract}
Abstrak
Iklan kosmetik tidak hanya berfungsi sebagai bagian dari bisnis semata tetapi juga menjadi arena kontestasi, negosiasi, dan resistensi konstruksi identitas perempuan muslim Indonesia Tulisan ini bermaksud menganalisis identitas perempuan muslim kontemporer Indonesia melalui iklan kosmetik muslim Wardah.Hasil analisis menunjukkan identitas perempuan muslim yang dibangun adalah tidak hanya sosok perempuan urban yang berpendidikan, taat pada ajaran agama, dan sopan tetapi juga dituntut untuk bersikap kosmopolit. Selain itu, iklan Wardah juga menjadi sarana negosiasi dan resistensi pemahaman ajaran Islam dan stigma media menuju ramah terhadap perempuan. Perempuan muslim Indonesia kontemporer dicitrakan sebagai sosok yang aktif di ruang publik, berjiwa sosial tinggi, tidak bergantung pada lakilaki, dan memiliki agensi diri untuk menentukan masa depan kehidupannya.Dari analisis yang dilakukan juga menunjukkan posisi perempuan berhijab dalam iklan
\end{abstract}


Wardah memiliki posisi yang penting karena ia menjelma menjadi sosok otoritatif dalam menentukan keunggulan produk yang ditawarkan dalam iklan.

Kata Kunci: wardah, perempuan, kosmopolitan, Islam

\begin{abstract}
Cosmetics' advertising is not only a mere part of the business but also becomes an arena for contests, negotiations, and resistance to the construction of the identity of Indonesia's Muslim women. This paper aims to analyze the identity of Muslim women in contemporary Indonesia through Wardah Muslim cosmetics advertising. The result shows that the identity of Muslim women are not only an educated urban woman who is obedient to religion teachings and is also polite, but they are also forced to be cosmopolite. It also becomes the media of negotiation and resistance to interpretation of Islamic teachings and media that more hospitable to women. Muslim women in contemporary Indonesia imaged as an active figure in public spaces with a strong social spirit and independent to determine their future life. The position of a woman wearing "hijab" (a veil) in Wardah advertising has an important position because she has transformed into an authoritative figure to determine the excellence of products offered in the advertisement.
\end{abstract}

Keywords: Wardah, women, cosmopolitan, Islam

\title{
A. PENDAHULUAN
}

Dengan jumlah penduduk yang mencapai 250 juta jiwa, Indonesia merupakan salah satu pangsa pasar yang menjanjikan bagi produk-produk konsumer, khususnya produk kecantikan dan perawatan pribadi. Mengacu pada laporan yang dikeluarkan oleh Global Healthcare Team (2016:5) pada tahun 2027 Indonesia diprediksikan akan masuk ke dalam lima besar negara di dunia yang paling banyak mengonsumsi 
kedua produk tersebut. Pesatnya pertumbuhan kelas menengah dan meningkatnya pendapatan membuat tren pengkonsumsian produkproduk tersebut setiap tahun semakin naik. Hal ini misalnya tercermin pada belanja iklan yang dikeluarkan pada tahun 2016 yang mencapai angka Rp150 triliun atau meningkat 8 persen dari tahun sebelumnya (Redaksi). Capaian belanja iklan tersebut didominasi oleh produk kecantikan, industri makanan dan minuman, dan otomotif. Laporan yang disusun oleh Global Healthcare Team juga menyebutkan selain meminati produk-produk yang dikeluarkan oleh perusahaan-perusahaan bermerek internasional seperti Unilever, L'Oreal, dan lain-lain, muncul keinginan dari konsumen Indonesia untuk mengonsumsi produk-produk yang dianggap sesuai dengan nilai-nilai keagamaan, seperti kosmetik halal.

Munculnya permintaan pemenuhan kebutuhan produk-produk yang dianggap sesuai dengan nilai-nilai keislaman dalam dunia konsumsi adalah fenomena yang menarik. Selepas masa reformasi, ekspresi keislaman tumbuh menguat dalam kehidupan masyarakat Indonesia. Heryanto (2015: 53-54) memaparkan menguatnya ekspresi keislaman merupakan akumulasi dari tumbuhnya masyarakat muslim kelas menengah Indonesia pasca-Orde Baru yang menempati posisi strategis dalam masyarakat baik secara ekonomi, sosial, pendidikan maupun politik. Hal ini mengakibatkan kelas menengah tersebut membutuhkan produk-produk gaya hidup yang dipandang sesuai dengan ekspresi dan identitasnya, yaitu Islam. Oleh karena itu, menurut Heryanto (2015:47) konsumerisme dalam hal ini tidak selalu bertentangan dengan nilai keagamaan tetapi dapat saling menyerap satu sama lain sehingga menimbulkan penanda identitas yang baru. Salah satu produk konsumer yang mencuat tersebut adalah produk kosmetik halal perempuan yang dimotori oleh Wardah.

Wardah menjelma menjadi salah satu produk yang paling menonjol dalam memenuhi kebutuhan gaya hidup pribadi perempuan muslim kontemporer di Indonedia. Pelan tapi pasti Wardah memberikan wacana alternatif yang berbeda dengan produk kecantikan lain yang dikeluarkan perusahaan multinasional seperti Unilever, Beiersdorf, dan L'Oreal yang tidak secara khusus menyasar konsumen perempuan Muslim. Wardah secara eksplisit menunjukkan melalui iklan-iklannya bahwa perempuan muslim dapat berkembang dan hidup seperti perempuan lain yang muncul dalam iklan-iklan kosmetik pada umumnya yaitu dapat bekerja, berumah 
tangga, bepergian ke luar negeri, dan beragam aktivitas lain tanpa harus risau dengan permasalahan tampilan diri.

Menurut Sari (2017: 537), Wardah ingin menunjukkan citra bahwa hijab tidak akan menghalangi seorang perempuan untuk bergerak dan terlihat menarik. Walaupun begitu, menurutnya iklan yang yang ditampilkan oleh produk Wardah tidaklah berbeda dengan produk kosmetik pada umumnya, yang membedakan adalah hijab yang dipakai oleh para model iklan Wardah. Namun demikian, citra yang ditampilkan oleh Wardah tidaklah sesederhana ingin menunjukkan kebebasan aktivitas perempuan berhijab di Indonesia tetapi di dalamnya terdapat nilai resistensi dan negosiasi terhadap nilai-nilai keperempuanan (womanhood) yang muncul di masyarakat Indonesia. Beberapa kajian mengenai iklan Wardah yang selama ini telah dilakukan lebih banyak berfokus pada konstruksi kecantikan (lihat misalnya kajian Worotitjan, 2014;Situmeang, 2015; Herlina, Akadafi, \& Hanana, 2016), budaya konsumsi (Sari, 2017), atau representasi pakaian (Dewi). Belum banyak kajian yang memberikan gambaran secara utuh bagaimana identitas perempuan muslim Indonesia kontemporer diperformasikan dalam iklaniklan yang ditampilkan oleh produk Wardah, khususnya yang bertalian dengan wacana keperempuan di Indonesia. Melalui tulisan ini saya juga berargumentasi bahwa iklan tersebut juga berusaha memberikan warna lain terhadap interpretasi ajaran agama Islam, khususnya yang berkaitan dengan agensi perempuan muslim, yang selama ini cenderung dinarasikan secara sepihak oleh media global sebagai sosok yang teropresi, submisif, dan dipandang terbelakang (Carland, 2011; Es, 2017; Ali, 2017). Selain itu, identitas perempuan muslim yang muncul dalam iklan Wardah juga tidak dapat dilepaskan dari perkembangan arus globalisasi perpindahan barang dan manusia sehingga menyebabkan watak identitas perempuan muslim di Indonesia yang tecermin dalam iklan Wardah lebih bersifat kosmopolitan dan lembut dibandingkan dekade sebelumnya. Bagian selanjutnya akan dipaparkan mengenai hubungan antara iklan dan perempuan sebagai latar belakang teoritis.

Dalam dunia bisnis, periklanan adalah salah satu unsur terpenting yang tidak dapat diabaikan dalam pemasaran sebuah produk kepada para konsumen. Macdonald (2004:41) menyebutkan hampir sebagian besar iklan yang bermunculan menempatkan posisi perempuan sebagai target utama konsumen. Bahkan beberapa wacana yang berkembang 
mengasosiasikan perempuan dengan kegiatan konsumer sebagai sesuatu hal yang tidak dapat dipisahkan. Walaupun demikian, permasalahan yang muncul adalah iklan berubah menjadi sebuah media yang dapat melanggengkan stereotip gender yang pada akhirnya menempatkan salah satu jenis kelamin dipandang lebih superior dibandingkan yang lain.

Permasalahan menjadi rumit, karena manusia belajar nilai dan persepsi sosial dari apa yang dilihatnya secara terus menerus seperti melalui tontonan televisi (Bandura, 2001:267; Grau \& Zotos, 2016:762). Manusia belajar mengenai kebiasaan, nilai, dan mencerna informasi termasuk peran gender dari apa-apa yang ditampilkan oleh televisi. Para penonton secara tanpa sadar dipaksa untuk mempraktikan segala informasi dan nilai yang ditampilkan oleh media. Salah satu hal yang paling kuat adalah iklan karena sifatnya yang cenderung persuasif dalam konten-konten yang ditampilkan.

Dalam konteks dunia barat, Sheehan (2003) menunjukkan bahwa keberadaan iklan berperan dalam menciptakan pelanggengan nilai-nilai patriarki yang menempatkan perempuan ke dalam posisi yang inferior dibandingkan laki-laki. Wood (1994:31) mengungkapkan media, iklan termasuk di dalamnya, sering menggambarkan laki-laki dan perempuan secara stereotipikal, tidak nyata, dan dengan persepsi yang terbatas. Setidaknya menurut Wood ada tiga pola yang dibangun oleh media dalam merepresentasikan gender yaitu perempuan menjadi pihak paling inferior dibandingkan laki-laki. Hal ini berimplikasi pada pengagungan lakilaki sebagai pihak utama dan pada akhirnya menyebabkan perempuan dianggap sebagai sosok yang tidak penting. Kedua, perempuan dan laki-laki digambarkan secara stereotip misalnya laki-laki lebih kuat dan perempuan lemah atau laki-laki bekerja dan perempuan di rumah yang pada akhirnya semakin menguatkan nilai-nilai patriarki di masyarakat. Ketiga, penggambaran hubungan antara laki-laki dan perempuanyang sering menekankan pada peran tradisional dan membiarkan "kekerasan" terhadap perempuan.

Melalui perkembangan globalisasi dan makin terkoneksinya dunia, gambaran tersebut juga merembes pada peredaran iklan di seluruh dunia. Iklan-iklan yang ditampilkan memiliki pola serupa yang secara stereotip menggambarkan kehidupan laki-laki dan perempuan. Matthes, Prieler, \& Adam (2016:315-316) melalui risetnya tentang iklan 
televisi yang beredar di berbagai belahan dunia misalnya menunjukkan perempuan selalu ditempatkan pada iklan yang dianggap berhubungan dengan dunia domestik seperti produk kecantikan, perawatan diri, perlengkapan mandi, kebutuhan rumah tangga, dan produk pembersih. Adapun laki-laki pada umumnya sering ditempatkan pada iklan-iklan yang berhubungan dengan teknologi seperti telekomunikasi, elektronik, computer, dan lain-lain. Begitupun jika dilihat dari seting yang digunakan, perempuan sering digambarkan dengan seting perumahan sedangkan laki-laki lebih bervariatif dan cenderung berada dalam ruang publik.

Ford, Voli, HoneycuttJr, \& Casey(1998:118)jugamengindikasikan bahwa pola-pola stereotip iklan yang berkembang di Barat, khususnya Amerika, juga telah menjadi pola iklan di Asia. Setidaknya terdapat beberapa pola stereotip iklan di Barat yang juga muncul dalam iklan di Asia misalnya di Jepang, seperti menempatkan perempuan sebagai sosok yang bergantung pada laki-laki, dipandang sebagai objek seksual dan hanya dilihat berdasarkan kemenarikan fisik, pengguna produk/ demonstrator atau bukan sebagai pihak otoritas yang menyediakan argumentasi mengenai kelebihan yang dimiliki oleh sebuah produk, dan usia yang ditampilkan cenderung lebih muda dibandingkan dengan usia laki-laki yang tampil dalam iklan.

Walaupun demikian, dari penelitian yang lain dapat dilihat bahwa tidak semua stereotip Barat mengenai perempuan ditampilkan begitu saja dalam iklan yang beredar di Asia. Frith, Cheng, \& Shaw (2004:58) ketika melakukan perbandingan antara model perempuan Asia dan Barat yang ditampilkan dalam majalah yang beredar di Singapura, Amerika, dan Taiwan menunjukkan bahwa terdapat perbedaan tampilan antara model Asia dan Barat. Model-model Barat cenderung tampil dengan pakaian yang lebih terbuka dibandingkan model Asia. Selain itu, secara seksual model perempuan dari Barat cenderung lebih liberal dibandingkan model perempuan dari Asia. Produk-produk yang ditampilkan pun berbeda yaitu model Asia sering muncul dalam iklan perawatan diri sedangkan model Barat mendominasi dalam kategori pakaian. Perbedaan ini muncul akibat latar belakang kebudayaan yang melandasi kehidupan para model. Davis, sebagaimana dikutip Frith, Cheng, \& Shaw (2004:55) misalnya menemukan bahwa di Korea Selatan iklan-iklan yang menampilkan produk-produk yang dianggap bermuatan erotis seperti lingerie tidaklah ditampilkan oleh model dari Asia, khususnya Korea Selatan, tetapi 
cenderung dipilih model yang berasal dari Barat. Model dari Asia cenderung tampil dalam iklan kebutuhan rumah tangga dan produk domestik. Hal ini dapat muncul disebabkan kultur Asia, khususnya Korea Selatan, yang menganggap perempuan harus menjaga kehidupan seksualnya dalam ranah privat dibandingkan perempuan Barat yang dianggap lebih terbuka dalam masalah seksualitas.

Di Indonesia salah satu iklan yang banyak mempengaruhi kehidupan perempuan Indonesia adalah iklan kecantikan khususnya produk-produk pemutih wajah. Wacana kulit putih dengan wanita Kaukasian sebagai citra ideal kecantikan mendominasi standar kecantikan perempuan Indonesia. Hal ini disebarluaskan melalui iklaniklan yang berasal dari perusahaan multinasional seperti Lux dan Giv yang menargetkan kaum perempuan Indonesia dari berbagai macam kalangan. Saraswati (2017:17-20) memaparkan bahwa orientasi kulit putih dengan citra ideal perempuan Kaukasian memiliki kaitan dengan berbagai institusi pemerintahan yang ada di Indonesia, baik penjajah Belanda dan Jepang maupun pemerintahan Indonesia sendiri. Selain itu, kajian Prabasmoro (2003:106) menunjukkan bahwa wacana kulit putih pada perempuan Indonesia yang ditampilkan melalui iklan sabun tidak hanya terbatas pada afirmasi standar kecantikan perempuan semata tetapi berkaitan erat dengan sistem kelas, ras, dan pertarungan wacana globalisasi dan kelokalan.

Walaupun demikian, menurut Purnama \& Safira (2017:44) analisis mengenai hubungan antara iklan dan agama, khususnya Islam di Indonesia pada masa kontemporer, masih kurang banyak dipilih oleh para peneliti sebagai bahan kajian. Kebanyakan peneliti memilih untuk mengkaji produk-produk budaya populer Islam yang lain seperti film, musik, ataupun karya sastra. Oleh karena itu, tulisan ini akan berfokus pada beberapa iklan televisi produk Wardah yang dapat dipandang sebagai salah satu pionir dalam produk kecantikan muslim di Indonesia. Selain itu, keberadaan iklan dapat juga dipandang sebagai arena pertarungan wacana yang di dalamnya terdapat hasrat, konstruksi, dan nilai ideal yang diidamkan oleh sebuah kelompok masyarakat. Dengan menganalisis iklan, dapat diketahui bagaimana hal-hal tersebut digambarkan melalui media visual. Selain itu, tren belanja iklan Indonesia makin tahun makin meningkat.Tahun 2011-2016 merupakan salah satu periode ketika belanja iklan televisi di Indonesia mengalami peningkatan yang 
signifikan. Belanja iklan yang pada tahun 2011 hanya mencapai kisaran angka 44,3 triliun rupiah meroket tajam ke angka 150 triliun rupiah pada tahun 2016(Redaksi).. Peningkatan angka ini disebabkan tingginya minat masyarakat Indonesia terhadap berbagai produk iklan yang ditawarkan melalui televisi, salah satunya produk Wardah.

Pada tulisan ini, analisis berfokus pada citra perempuan muslim yang ditampilkan pada iklan televisi Wardah. Analisis dilakukan berdasarkan metode yang dilakukan oleh Prieler, Ivanov, \& Hagiwara, (2015:31-32)saat menganalisis iklan televisi yang terdiri atas beberapa langkah yaitu melihat siapa yang menjadi tokoh utama penceritaan, melihat siapa yang tampak lebih lama secara close ups muncul dalam iklan, melihat siapa yang lebih muncul dalam iklan, melihat siapa yang secara substansial memberikan informasi mengenai produk atau layanan dari iklan, melihat siapa yang menggunakan produk dalam iklan dan melihat siapa yang memiliki waktu berbicara lebih lama dalam iklan. Langkah-langkah tersebut akan dipergunakan secara simultan untuk menelisik bagaimana resistensi, negosiasi, dan kosmopolitanisme perempuan muslim dihadirkan dalam iklan Wardah.

\section{B. PEMBAHASAN}

\section{Kosmopolitanisme dan Otoritas Perempuan Muslim}

Menurut Purnama \& Safira (2017:47), terdapat beberapa ketentuan khusus yang harus dipenuhi oleh sebuah iklan ketika mengenalkan produknya kepada masyarakat Muslim seperti tidak boleh menggambarkan perilaku amoral, penggunaan bahasa yang sopan, tidak mempergunakan unsur seks atau hal yang menakutkan untuk menarik peminat, tidak berlebihan dalam memberikan klaim produk yang ditawarkan (tidak berbohong), dan pakaian yang ditampilkan para model harus sesuai dengan aturan Islam (perempuan harus memakai pakaian tertutup dan berhijab, kecuali wajah dan tangan). Seluruh iklan Wardah tampaknya berusaha mengikuti ketentuan ini. Iklan Wardah hampir sebagian besar mempergunakan artis berhijab sebagai model. Beberapa iklan seperti yang muncul dalam iklan bertajuk Everyday Colors dan Wardah Exclusive Matte Lip Cream menampilkan beberapa model yang tidak berhijab. Walaupun penempatan model-model yang tidak memakai hijab ini dapat dipandang sebagai perluasan konsumen, tetapi jika ditelisik lebih jauh ada hal menarik yang ditampilkan yaitu yang terkait dengan relasi kekuasaan bukan 
hanya persoalaan bisnis semata. Jika Ford, Voli, Honeycutt Jr, \& Casey (1998:114) menyimpulkan bahwa perempuan dalam relasinya dengan laki-laki pada iklan hanya sebatas sebagai pengguna produk/demonstrator atau bukan sebagai pihak otoritas yang menyediakan argumentasi mengenai kelebihan yang dimiliki oleh sebuah produk, maka dalam iklan wardah, relasi tersebut berubah antara model yang berhijab dan model yang tidak berhijab. Model yang berhijab menjadi pihak yang memiliki otoritas untuk menjustifikasi keunggulan produk yang ditampilkan dibandingkan para model yang tidak berhijab. Walaupun para model, baik yang berhijab maupun tidak berhijab, ditampilkan bersama-sama atau memiliki yang scene yang hampir sama, narasi produk sebagian besar disampaikan oleh model yang berhijab (gambar 1).

Selain itu, para model yang berhijab digambarkan sebagai sosok yang solutif dalam menghadapi permasalahan kecantikan yang dialami oleh perempuan. Dalam konteks iklan Wardah, permasalahan ini dialami oleh perempuan (model) yang tidak berhijab (gambar 2). Dari hal tersebut dapat ditafsirkan bahwa muncul relasi kekuasaan yang menempatkan posisi model perempuan berhijab lebih unggul dibandingkan model yang tidak berhijab karena perempuan yang berhijab memiliki otoritas lebih tinggi dibandingkan yang lain.

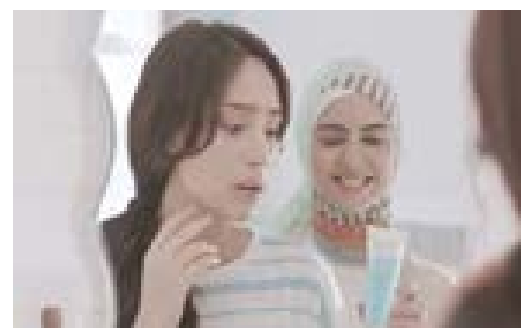

Gambar 1

Perempuan Berhijab Sebagai Pihak Otoritas

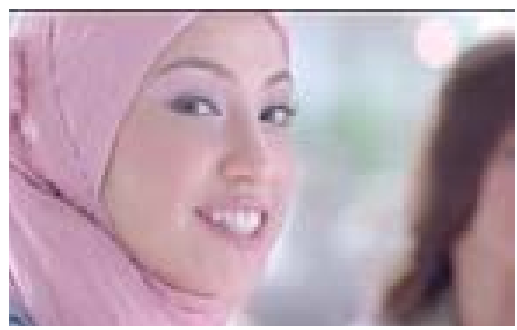

Gambar 2

Perempuan Berhijab Sebagai Sosok Solutif

Penempatan model berhijab sebagai pihak otoritas dalam iklan dapat dipandang sebagai resonansi konstruksi perempuan berhijab dalam masyarakat Indonesia kontemporer. Kajian Brenner, sebagaimana dikutip Izharuddin (2015:399), menunjukkan bahwa pemakaian jilbab dalam masyarakat Indonesia dipandang sebagai sosok yang telah mengalami pencerahan atau kesadaran jiwa yang unggul dibandingkan perempuan lain yang belum memakai jilbab. Handayani (2016:146) yang menganalisis pemakaian hijab kontemporer di Indonesia juga memiliki 
simpulan yang tidak berbeda jauh. Menurutnya hijab yang dipakai oleh perempuan Indonesia menjadi penanda identitas antara masa lalu yang "kelam" dengan kehidupan yang lebih cerah dengan memakai hijab.

Sari (2017:537) mengemukakan bahwa sebenarnya tidak ada perbedaan antara iklan produk kosmetik Wardah dan kosmetik yang lain, yang membedakan hanyalah model yang ditampilkan, yaitu iklan Wardah menampilkan model berhijab saja. Namun demikian, saya melihat bahwa terdapat perbedaan antara iklan Wardah dan iklan kosmetik lainnya dalam segi tata cara penggambaran budaya konsumer yang ditampilkan oleh produk Wardah. Iklan Wardah berusaha membangun citra kecantikannya dengan mengaitkan pada dua aktivitas yang dapat dilakukan oleh perempuan yaitu aktivitas mencari nafkah (bekerja) dan sosial (membantu sesama). Hal ini berimplikasi pada citra kosmopolitan muslim Indonesia yang dicoba dibangun oleh iklan Wardah.

Dalam analisisnya, Saraswati (2017:156-162) mengemukakan terdapat beberapa cara yang dilakukan oleh iklan kecantikan di Indonesia untuk mengonstruksikan citra kosmopolitanisme dalam iklan seperti penggunaan model yang bukan orang Indonesia atau perempuan Indo dan penggunaan bahasa Inggris. Karakter kosmopolitan yang ditampilkan dalam iklan Wardah dibangun dalam beberapa cara di antaranya melalui relasi antara perempuan muslim dengan orang asing, baik secara personal maupun dalam kehidupan sehari-hari di masyarakat dan pengonstruksian produk Wardah sebagai bagian dari pergerakan kebudayaan global. Perempuan muslim yang muncul dalam iklan Wardah ditampilkan sebagai sosok urban yang tidak hanya aktif dalam lingkup lokal tetapi juga global. Karakter perempuan muslim seperti ini memiliki kemiripan yang sama dengan temuan dari Paramaditha (2011:507) saat mengkaji film-film yang muncul selepas reformasi di Indonesia, Dia menemukan bahwa karakter yang ditampilkan oleh para sineas dalam filmnya tidak hanya sebagai bagian dari kehidupan urban lokal tetapi juga dicitrakan sebagai bagian dari komunitas global dengan dunia barat sebagai acuan utama.

Jika dalam film Indonesia sebagaimana dikemukakan oleh Paramadhita, imajinasi kosmopolit ini dibangun melalui keikutsertaan tokoh dalam film dengan gerakan global seperti aktivitas go green dan MTV. Dalam iklan wardah, hal ini ditandai dengan masuknya perempuan 
muslim dalam kehidupan sehari-hari masyarakat global. Interaksi perempuan muslim dengan orang asing menjadi salah satu penanda penting citra kosmopolitan yang dibangun oleh iklan Wardah. Hal ini misalnya dapat dilihat dalam iklan Wardah yang berjudul Renew You selain model Inneke Koesherawati dicitrakan sebagai perempuan urban yang bekerja, ia juga digambarkan hidup di tengah-tengah kehidupan masyarakat global dengan penanda orang-orang di sekitarnya yang bukan berasal dari Indonesia (gambar 3).
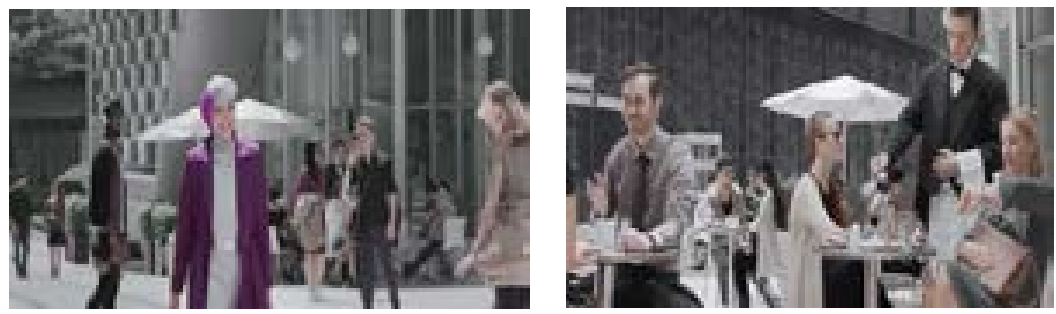

Gambar 3

Kehidupan Global dan Multikultural dalam Iklan Wardah

Gambaran ini dapat dipandang sebagai salah satu cara iklan Wardah dalam menampik citra yang ditampilkan dalam berbagai media. Es (2017:2-3) misalnya menjelaskan melalui berbagai gambaran yang terbatas, media di Barat, sering mengonstruksikan perempuan sebagai sosok yang teropresi, terbelakang, dan pada akhirnya timbul pemahaman bahwa nilai-nilai Islam tidak dapat hidup berdampingan atau bertentangan dengan nilai masyarakat Barat. Melalui iklan tersebut Wardah melakukan kontestasi terhadap stereotip Islam di media, khususnya perempuan muslim yang dapat hidup dan berinteraksi dengan nilai-nilai yang dianut oleh masyarakat barat (gambar 4).
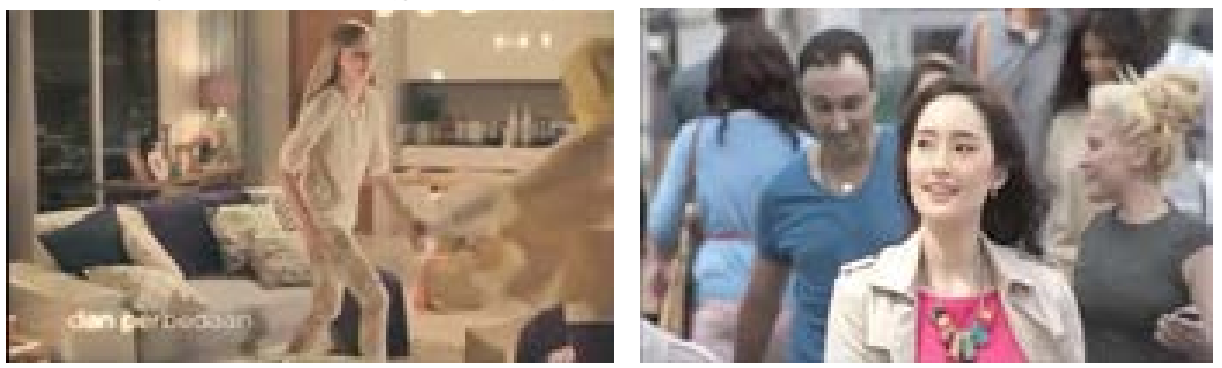

\section{Gambar 4}

Interaksi Perempuan Muslim dengan Masyarakat Global (asing)

Selain itu, iklan Wardah juga mengonstruksikan produk yang dikeluarkannya merupakan bagian dari pergerakan global. Hal ini 
misalnya dapat dilihat dari penggunaan setting Eropa dan Amerika Serikat sebagai latar iklan (gambar 5) dan keikutsertaan Wardah dalam pergerakan budaya global (gambar 6). Penggunaan latar Eropa dan Amerika Serikat menurut Saraswati (2017:114) merupakan sebuah tindak emotionscape yaitu hubungan antara keberadaan ruang dan ras yang sarat emosi. Menurutnya, Eropa dan AS terus ditampilkan bukan hanya sebagai negeri yang indah tetapi juga negeri dari mana kecantikan autentik berasal. Maka dari hal itu, para perempuan muslim yang mengonsumsi produk Wardah diimajikan sebagai bagian dari pergerakan global yaitu mengonsumsi produk yang dikonstruksikan berasal dari sumber kecantikan global dan bersama-sama masyarakat lain mengonsumsi produk yang sama.
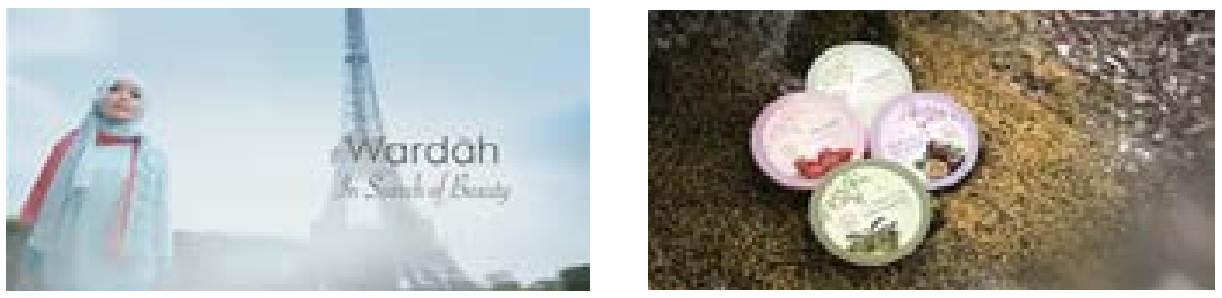

\section{Gambar 5}

Latar Eropa yang Dimunculkan dalam Iklan

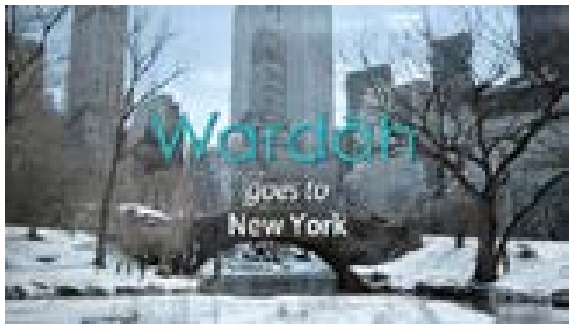

Gambar 6

Pergelaran Kebudayaan Dunia sebagai Pencapaian Nilai Kosmopolit

Upaya konstruksi kosmopolit perempuan muslim juga ditampilkan oleh Wardah melalui gambaran keikutsertaan Wardah pada pergelaran dunia seperti New York Fashion Week. Terdapat hasrat yang ingin dicapai oleh Wardah untuk mencitrakan perempuan muslim dapat hidup secara global. Hoesterey \& Clark (2012:210) mengemukakan perempuan muslim yang ideal di Indonesia dikarakterisasikan sebagai sosok yang sukses dan berpendidikan, romantik tetapi sopan tidak hanya tertutup dan taat dalam menjalankan aturan agama. Akan tetapi, 
jika melihat konstruksi citra yang ditampilkan dalam iklan Wardah karakterisasi tersebut tidaklah cukup. Selain sukses dan beredukasi, romantik tetapi sopan, perempuan muslim yang ideal harus juga memiliki wawasan global dan hidup secara kosmopolit di tengah situasi yang multikultural.

\section{Resistensi dan Negosiasi}

Analisis Sakai \& Fauzia (2016:244) terhadap kehidupan perempuan muslim pekerja di Indonesia menunjukkan bahwa terdapat beberapa strategi yang dilakukan oleh perempuan muslim di Indonesia agar dapat diizinkan untuk bekerja di luar rumah seperti halnya lakilaki. Ajaran Islam konservatif/tradisional menempatkan laki-laki sebagai pihak utama dalam upaya mencari nafkah dalam keluarga. Sakai dan Fauzia memaparkan untuk menghindari stigma sosial atas karier yang dibangun perempuan muslim pekerja di Indonesia selalu menekankan bahwa aktivitas mereka di ruang publik dilandasi atas izin suami. Menurutnya perolehan izin ini ditandai dan dinegosiasikan dengan tuntutan kepada perempuan untuk memenuhi tugas mereka sebagai istri dan ibu, sebelum para perempuan ini dapat bekerja di luar rumah. Negosiasi inilah yang menjadikan perempuan muslim pekerja di Indonesia dapat melunakkan atau memberikan interpretasi baru atas ajaran Islam konservatif yang menempatkan perempuan harus selalu berada dalam ranah domestik. Dengan demikian, ada dua kehidupan yang dijalani oleh perempuan muslim di Indonesia yang ingin bekerja di luar rumah.

Dalam konteks iklan Wardah, beberapa kali iklan Wardah menampilkan perempuan muslim Indonesia yang juga bekerja di luar rumah. Bekerja merupakan salah satu bentuk aktualisasi diri yang dapat dilakukan oleh perempuan muslim di Indonesia. Jika dalam kajian Sakai dan Fauzia proses negosiasi ajaran Islam yang menempatkan perempuan sebagai pihak inferior dalam mencari nafkah melalui strategi permintaan izin dari suami dan terpenuhinya kewajiban sebagai ibu dan istri yang harus dipenuhi perempuan, maka dalam iklan Wardah hal tersebut dinegosiasikan dengan aktivitas sosial, seperti membantu panti asuhan dan warga sekitar, yang dilakukan oleh para perempuan muslim (gambar7). 

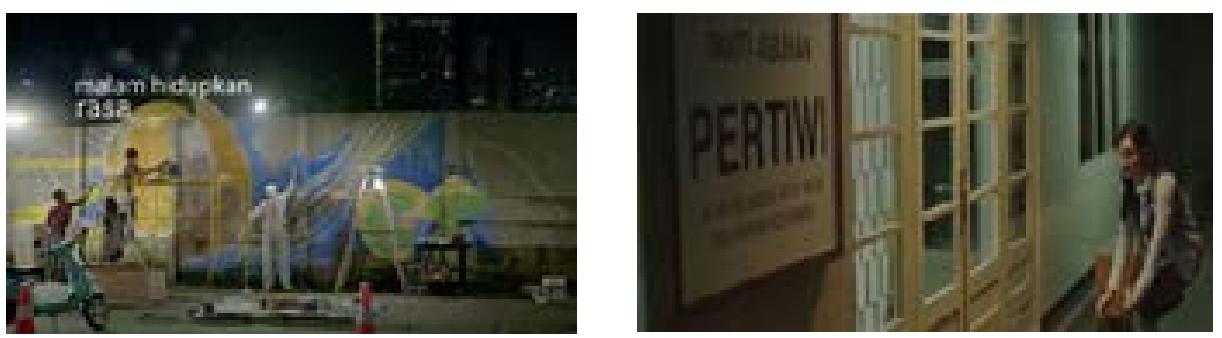

\section{Gambar 7}

Gambaran Aktivitas Sosial yang Dilakukan Perempuan Muslim dalam Iklan Wardah

Ajaran konservatif yang menempatkan perempuan sebagai pihak pasif dalam mencari nafkah dinegosiasikan oleh Wardah. Untuk menghindari kritikan, para perempuan muslim ditampilkan dalam dua dunia yaitu karier dan aktivitas sosial. Pemilihan aktivitas sosial sebagai alat negosiasi disebabkan perempuan yang ditampilkan dalam iklan Wardah dicitrakan sebagai perempuan muda yang belum menikah.Teks iklan Wardah menunjukkan bahwa perempuan memiliki beban moral yang harus dipenuhi agar mereka dapat bekerja dan mengaktualisasikan diri. Jika sudah menikah para perempuan yang ingin bekerja harus memenuhi kewajiban domestiknya terlebih dahulu sebelum bekerja, maka bagi mereka yang belum menikah disarankan untuk memiliki aktivitas sosial sebagai alat negosiasi. Berbeda misalnya dengan iklan Pond's Men yang dibintangi Rio Dewanto atau L'oreal Men Expert yang dibintangi Nicholas Saputra yang menunjukkan kehidupan pekerjaan masing-masing bintang yang tidak dibebani aktivitas sosial sebagaimana perempuan muslim saat bekerja. Dalam iklan Wardah, bekerja dan beraktivitas sosial menjadi cara para perempuan muslim Indonesia dari kalangan menengah untuk memberikan interpretasi yang lebih ramah terhadap ajaran Islam mengenai perempuan.

Upaya iklan Wardah untuk memberikan interpretasi yang lebih ramah terhadap perempuan juga tidak hanya berlaku dalam bidang pekerjaan tetapi juga menyangkut pernikahan dan urusan memilih jodoh. Interpretasi Islam tradisional dan konservatif yang menempatkan perempuan sebagai pihak pasif dalam pernikahan dinegosiasikan dalam salah satu iklan Wardah yang bertajuk halal dari awal (gambar 8). Saat salah seorang model yang digambarkan merupakan adik dari artis Inneke Koesherawati akan menikah ia berkata "Makasih ya semuanya." Kemudian Inneke Koesherawati menjawab: "Dari awal kamu sudah memilih yang terbaik." 


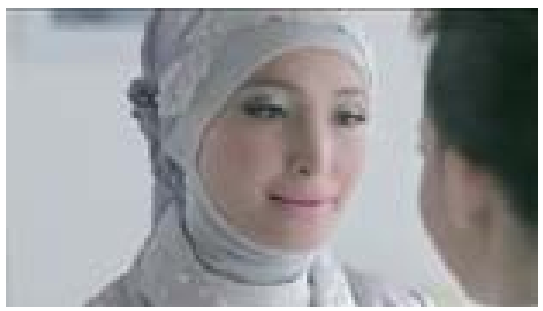

Gambar 8

Iklan Wardah Bertajuk Halal Dari Awal

Jawaban Inneke Koesherawati dari awal kamu sudah memilih yang terbaik memiliki dua tafsir. Pertama yang terkait dengan produk Wardah yang diartikan sebagai produk yang tepat dipilih oleh adik Inneke Koesherawati sehingga ia memiliki kulit yang diidamkan dan membawanya ke jenjang pernikahan. Kedua, jawaban tersebut dapat juga ditafirkan sebagai sebentuk agensi diri dari adik Inneke Koesherawati dalam menentukan kehidupannya, khususnya dalam memilih jodoh bagi pernikahannya. Dari iklan tersebut dapat ditafsirkan bahwa tidak selamanya perempuan muslim bergantung pada laki-laki. Hal ini dibuktikan bahwa perempuan muslim dapat memilih sendiri teman hidupnya. Iklan tersebut juga melakukan resistensi terhadap gambaran sepihak media barat yang mencitrakan perempuan muslim sebagai sosok yang teropresi dan submisif dibandingkan dengan laki-laki muslim yang dianggap lebih bebas.

Resistensi terhadap hal ini pada puncaknya dapat dilihat pada iklan Wardah bertajuk "Exclusive Series Sandra Dewi" dan "In Search Beauty" yang memperlihatkan perempuan muslim melakukan pesiar (traveling) secara mandiri di luar negeri, seperti Eropa dan Amerika (gambar 9). Wardah melakukan resistensi terhadap interpretasi ajaran Islam yang mengajarkan bahwa perempuan ketika bepergian harus bersama salah satu anggota keluarga yang lain. Iklan Wardah justru menampilkan model perempuan muslim yang secara mandiri bepergian ke luar negeri.
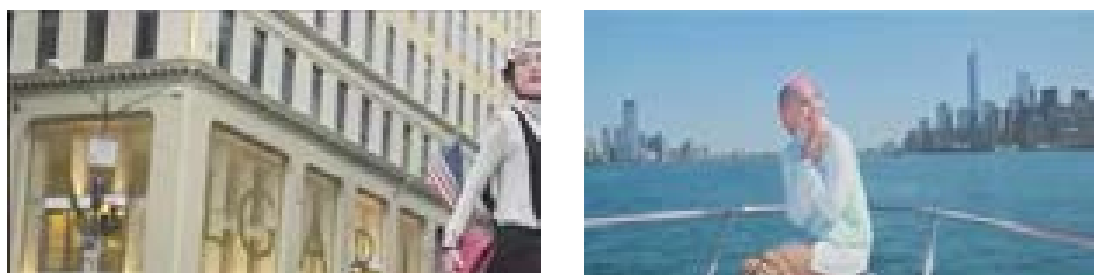


\section{Gambar 9}

Iklan Wardah yang Menunjukkan Aktivitas Perempuan Muslim Travelling

Dalam iklan ini dapat diinterpretasikan bahwa perempuan muslim, khususnya Indonesia, memiliki otoritas dan agensi tersendiri terhadap dirinya. Selain itu, perempuan muslim Indonesia dipandang tidak selalu bergantung pada keberadaan laki-laki dalam menentukan kehidupannya. Iklan yang ditampilkan oleh Wardah berusaha memberikan interpretasi lain terhadap ajaran Islam yang lebih ramah terhadap perempuan misalnya jika dibandingkan dengan perempuan muslim yang berada di Timur Tengah.

\section{SIMPULAN}

Dari analisis yang telah dilakukan dapat disimpulkan bahwa iklan kosmetik tidak hanya berfungsi sebagai bagian dari bisnis semata melainkan juga bagian dari pengonstruksian identitas perempuan muslim Indonesia. Dengan demikian, identitas perempuan muslim yang dibangun oleh Wardah bukan hanya sosok perempuan urban yang berpendidikan, taat pada ajaran agama, dan sopan tetapi juga dituntut untuk bersikap kosmopolit dengan bergabung pada pergerakan kebudayaan global, berinteraksi dengan orang asing, bahkan hidup di wilayah lain yang dalam hal ini wilayah barat. Sebagai sebuah produk kebudayaan, iklan Wardah juga menjadi situs resistensi dan negosiasi terhadap ajaran dan nilai agama yang konservatif. Upaya negosiasi terhadap ajaran agama Islam dapat dilihat dari gambaran aktivitas di ruang publik yang dilakukan oleh para perempuan muslim. Untuk menghindari stigma sosial dan ajaran agama yang menekankan perempuan untuk tidak bekerja, negosiasi yang dilakukan adalah dengan cara menyertakan kegiatan sosial dalam aktivitas publik yang dilakukan para perempuan muslim. Iklan Wardah juga berusaha memberikan interpretasi ajaran Islam yang lebih ramah terhadap perempuan, dengan melakukan resistensi atas tafsir yang menempatkan perempuan sebagai pihak yang submisif dan bergantung pada sosok lakilaki. Hal ini dapat dilihat melalui agensi yang dimiliki oleh perempuan muslim dalam memilih pasangan hidup atau bepergian ke tempat lain tanpa ditemani oleh salah seorang anggota keluarga. Dari analisis yang dilakukan juga menunjukkan posisi perempuan berhijab dalam iklan Wardah memiliki posisi yang penting karena ia menjelma menjadi sosok otoritatif dalam menentukan keunggulan produk yang ditawarkan. 


\section{DAFTAR PUSTAKA}

Ali, Mehrunnisa Ahmad. 2017. "Representation of Muslim Characters Living in the West in Ontario Language Textbooks Ontario." Intercultural Education Vol. 24 No. 5,2017.

Bandura, A. 2011. "Social Cognitive Theory of Mass Communication." Media Psychology Vol 3, 2011.

Carland, Susan. 2011 "Islamophobia, Fear of Loss of Freedom, and the Muslim Woman.” Islam and Christian-Muslim Relations 6410. September,2011.

Dewi, Murti Candra. 2013 "Representasi Pakaian Muslimah Dalam Iklan (Analisis Semiotika Charles Sanders Peirce Pada Iklan Kosmetik Wardah Di Tabloid Nova)." Jurnal Komunikasi PROFETIK Vol. 6 No. 2,2013

Es, Margaretha A Van. 2017. "Global Studies in Culture and Power Muslim Women as 'ambassadors' of Islam : Breaking Stereotypes in Everyday Life." Identities: Global Studies In Culture And Power, 2017

Ford, John B et al. 1998. "Gender Role Portrayals in Japanese Advertising : A Magazine Content Analysis Gender Role Portrayals in Japanese Advertising : A Magazine Content Analysis." Journal of AdvertisingVol. 27 No.1, 2017

Frith, Katherine Toland, Hong Cheng, and Ping Shaw. 2004. "Race and Beauty : A Comparison of Asian and Western Models in Women 'S Magazine Advertisements." Sex Roles Vol. 50. 53-61 January2004

Global Healthcare Team. Indonesia: Personal Care \& Cosmetics Products. 2016. N.p., 2016. Print.

Grau, Stacy Landreth, and Yorgos C. Zotos. 2016 "Gender Stereotypes in Advertising : A Review of Current Research Gender Stereotypes in Advertising : A Review of Current Research." International Journal of Advertisingvol 35, August 2016. 
Handayani, Linda.2016. Hijab Style Undercover: Ideologi

Konsumerisme Dan Kebebasan Dalam Menutup Aurat.

Yogyakarta: nulisbuku.com

Herlina, Indhie Febrianti, Riri Akadafi, and Alna Hanana. 2016. "The

Construction of the Meaning of Beauty by the Representation of

Wardah Halal Beauty." International Journal of Humanities and

Social Sciences Vol. 3 No. 5, 2016

Heryanto, Ariel. 2015.Identitas Dan Kenikmatan: Politik Budaya Layar Indonesia. Jakarta: Kepustakaan Populer Gramedia.

Hoesterey, James B, and Marshall Clark. 2012. "Film Islami : Gender, Piety and Pop Culture in Post- Authoritarian Indonesia." Asian

Studies Reviewvol. 36 No.2 207-226 2012

Izharuddin, Alicia. 2015. "The Muslim Woman In Indonesian Cinema And The Face Veil As 'Other '." Indonesia and the Malay WorldVol 43 No. 126,2015

Macdonald, Myra.2004. "From Mrs Happyman To Kissing Chaps Goodbye: Advertising Reconstruct Femininity." dalamCritical Reading: Media and Gender. Ed. Cynthia Carter and Linda

Steiner. Berkshire, England: Open University Press,

Matthes, Jörg, Michael Prieler, and Karoline Adam. 2016. "GenderRole Portrayals in Television Advertising Across the Globe." Sex Roles Vol. 75,2016

Paramaditha, Intan. 2011. "City and Desire in Indonesian Cinema." Inter-Asia Cultural StudiesVol. 12 No.4,2011

Prabasmoro, Aquarini Priyatna. 2003. Becoming White: Representasi Ras, Kelas, Femininitas Dan Globalitas Dalam Iklan Sabun. Yogyakarta: Jalasutra.

Prieler, Michael, Alex Ivanov, and Shigeru Hagiwara. 2015. "Gender Representations in East Asian Advertising : Hong Kong, Japan, and South Korea." Communication \& SocietyVol 28 No. 1. 
Purnama, Fadhil Akbar, and Anya Safira. 2017 "Investigating Islamic Advertising Ethics : Perceptions of Indonesian Muslims." Journal of Emerging Economies \& Islamic Research Vol. 5 No.2, 2017.

Redaksi. 2016. "Belanja Iklan Pada 2016 Mencapai Rp150 Triliun." Kompas, Belanja Iklan pada 2016 Mencapai Rp150 Triliun. Kompas. Jakarta. Retrieved from https://www.pressreader.com/ indonesia/kompas/20170126/281956017500582

Sakai, Minako, and Amelia Fauzia. 2016. "Performing Muslim Womanhood : Muslim Business Women Moderating Islamic Practices in Contemporary Indonesia." Islam and ChristianMuslim Relations Vol.27 No.3, 2016

Saraswati, L. Ayu. 2017.Putih: Warna Kulit, Ras, Dan Kecantikan Di Indonesia Transnasional. Serpong: Marjin Kiri

Sari, Wahyu Triana. 2017. "Cosmetics and Consumption (An Analysis of Consumption Culture in Wardah Cosmetic Products Selection )." International Journal of Social Science and Humanity Vol.7 No.8, 2017

Sheehan, Kim Bartel.2003.Controversies in Contemporary Advertising. New York: Sage Publications.

Situmeang, Ilona Oisina. 2015. "Representasi Wanita Pada Iklan Televisi Wardah Cosmetic (Analisis Semiotik Roland Barthes Wardah Inspiring Beauty Versi True Colours).” SemiotikaVol. 9 No.1, 2015

Wood, Julia T. 1994 "Gendered Media : The Influence of Media on Views of Gender." Communication, Gender, and Culture. Wadsworth Publishing.

Worotitjan, Hulda Grace. 2014. "Konstruksi Kecantikan Dalam Iklan Kosmetik Wardah.” Jurnal E-KomunikasiVol. 2 No.2,2014. 